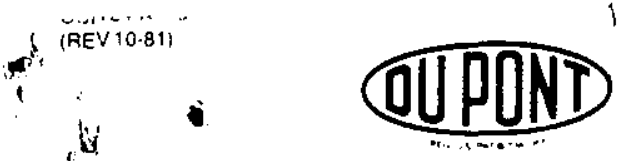

E. I. du Pont de Nemours \& Company InCORTORATEO

ATOMIC ENERGY DIVISION

SAVANNAH RIVER LABORATORY AIKEN, SOUTH CAROLINA 29808-0001

(TWX 810.771-2670 TEL 803-725-6211 WU AUGUSTA GA)

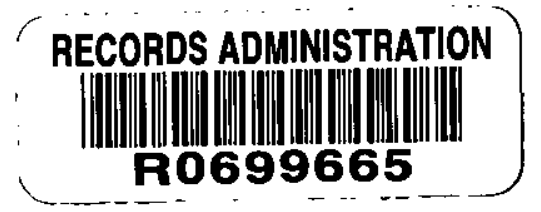

J. T. GRANAGHAN, MANAGER

SAVANNAH RIVER PLANT, 703-A

ATTENTION: G. T. WRIGHT (15), 703-H
DPSTD-87-2-TL

Keywords: Waste Site closure Burial Ground

CC: J. E. Haywood, 703-F
C. R. Sherman, 703-A
E. J. O'Rourke, 703-F
J. N. Beatty, 703-H
G. W. Becker, 703-H
R. H. Batig, 247-F
B. D. Helton, 703-H
M. A. Katz, 703-H
C. B. Stevens, 703-H
S. W. Hixson, 703-A
J. T. Lowe, SRL, 773-A
D. L. McIntosh, 773-A
J. A. Stone, 773-41A
H. F. Sturm, Jr. 773-43A
E. L. Wilhite, 773-43A
R. H. Hawkins, 773-43A
B. B. Looney, 773-42A
J. R. Cook, 773-43A
SRL Records (4) 773-A

August 17,1987

The attached Technical Data Summary describes a plan for the closure of the 643-G radioactive waste burial ground. The strategy used in this plan is consistent with that selected as the preferred alternative in the Draft Environmental Impact statement on waste Management Activities for Groundwater Protection, i.e. a combination of remediation, stabilization, and capping.

Remedial action will consist of exhuming culverts of transuranic waste which are retrievably stored in trenches within 643-G, and closing the grid wells at the site. The emptied solvent tanks at 643-G wll be stabilized in place. A closure cap consisting of native soil, low-permeability clay, and gravel will be emplaced over the site to assure long-term physical and chemical stability.

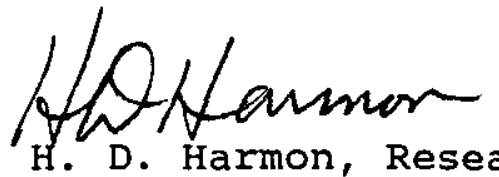


DPSTD $-87-2$

TECHNICAL DATA SUMMARY

\section{PLAN FOR CLOSURE OF THE 643-G BURIAL GROUND}

Prepared by: James $R$. Cook

August 1987

Approved by: H. D. Harmon, Research Manager Interim Waste Technology Division

Issued by: E. I. du Pont de Nemours and Company Savannah River Laboratory Aiken, South Carolina 29808 


\section{TECHNICAL DATA SUMMARY \\ PIAN FOR CLOSURE OF THE 643-G BURIAL GROUND}

\section{TABLE OF CONTENTS}

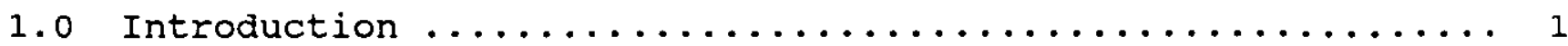

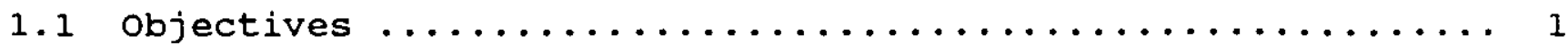

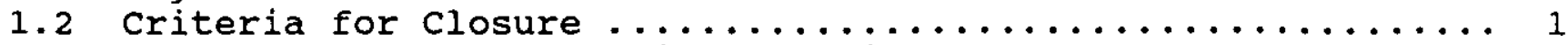

1.2.1 Protect from Percolation of Rainwater ................ 1

1.2.2 Promote Drainage and Prevent Erosion ............... 2

1.2.3 Minimize Maintenance ....................... 2

1.2 .4 Protect Against wind Dispersal of waste ............. 2

1.2.5 Protect Against Contact with Waste by Human

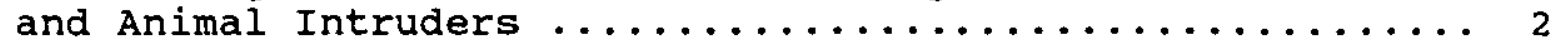

1.2.6 Prevent "Bathtub Effect" ....................... 2

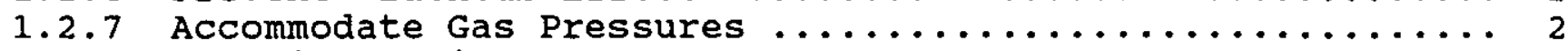

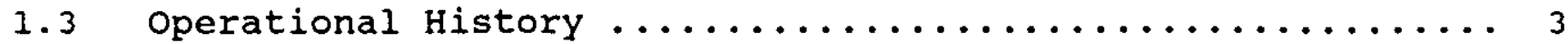

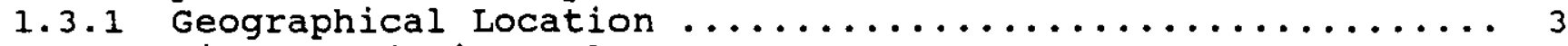

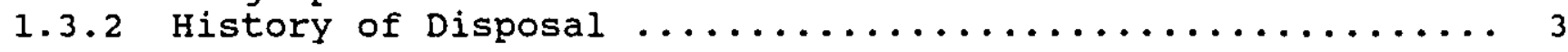

2.0 Closure Actions - Stabilization, Waste Removal,

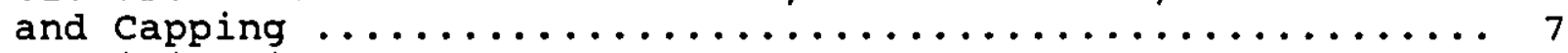

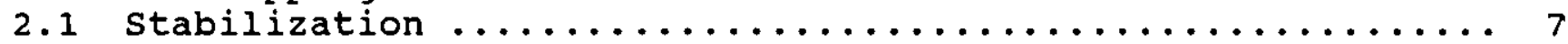

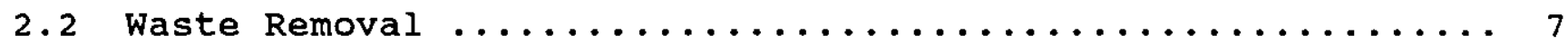

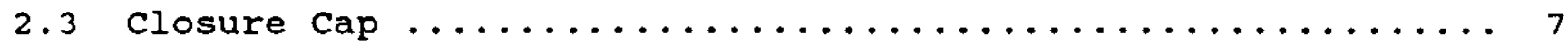

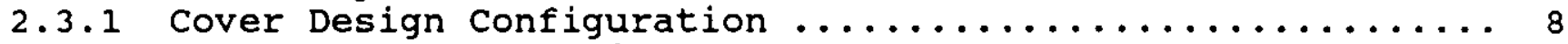

2.3 .2 Cover cap Construction ....................... 8

3.0 Additional Design Considerations $\ldots \ldots \ldots \ldots \ldots \ldots \ldots \ldots$

3.1 Initial site conditions ........................ 13

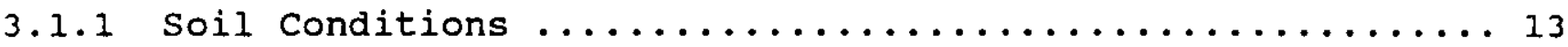

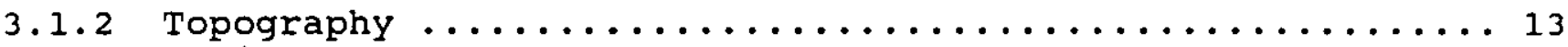

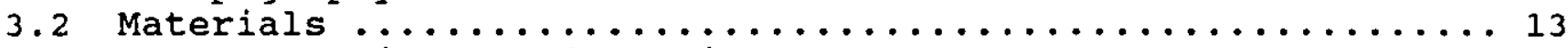

3.3 Surface Drainage and Erosion Control ................. 15

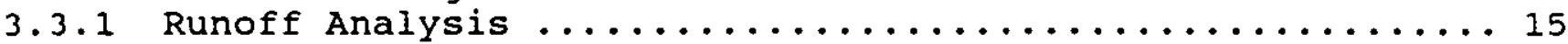

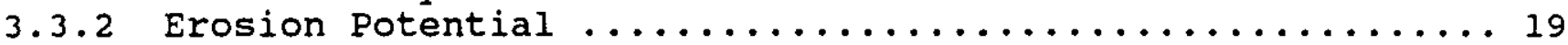

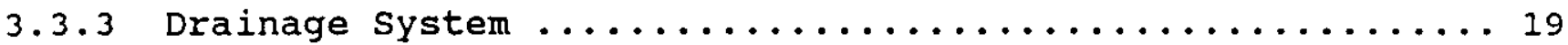

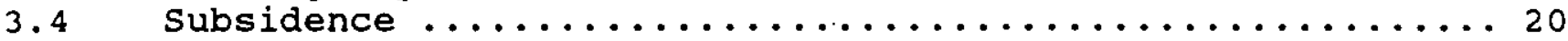

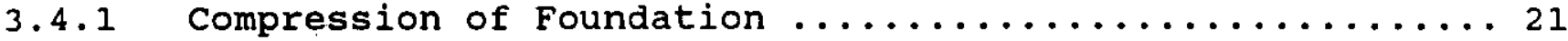

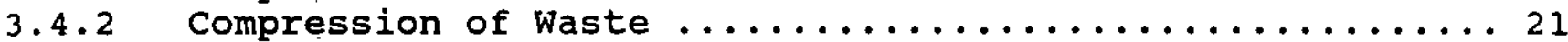

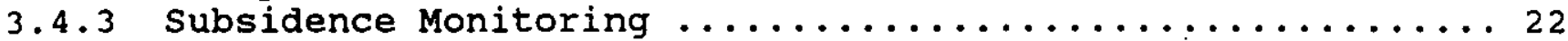

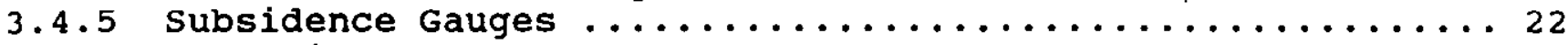

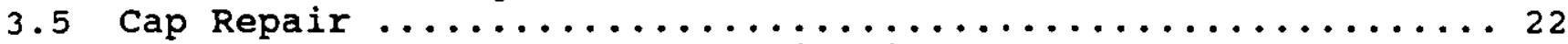

3.6 Post-Closure Ground Water Monitoring ............... 23

References $\ldots \ldots \ldots \ldots \ldots \ldots \ldots \ldots \ldots \ldots \ldots \ldots \ldots \ldots \ldots \ldots \ldots \ldots \ldots \ldots$ 


\section{LIST OF FIGURES}

Figure 1 Map of the Radioactive Waste Burial

Ground Area ......................... 4

Figure $2 \quad$ Plan View of Cap Design ................. 9

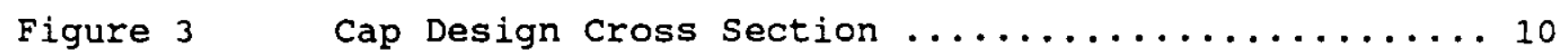

Figure 4 Topography and Drainage in the Vicinity

of the 643-G Radioactive Waste Burial Ground ..... 14

\section{IIST OF TABLES}

Table 1 Inventory of Hazardous and Radiological

Constituents at the $643-G$ site ............... 6

Table 2 Precipitation Data From SRP and Vicinity ....... 17

Table $3 \quad$ Rainfall Intensity and Frequency ........... 18 


\section{TECHNICAL DATA SUMMARY \\ PLAN FOR CLOSURE OF THE 643-G BURIAL GROUND}

\subsection{Introduction}

\subsection{Objectives}

The actions leading to closure of $643-G$ will involve a combination of waste removal, stabilization, and capping. The overall effect of the closure actions will be to place the 643-G site in a physically and chemically stable state which will remain stable over a long period of time. During a one-hundred year institutional control period surveillance and monitoring of the site will be carried out to verify that the performance of the system is acceptable, and access of the general public to the site will be restricted. Closure of $643-\mathrm{G}$ has been addressed in the recent draft Groundwater Protection EIS. 1

\subsection{Criteria for closure}

The closure system will be designed to meet the following criteria:

- Minimize percolation of rainwater into the disposed waste.

- Promote drainage away from the buried waste.

- Function with minimum maintenance.

- Prevent erosion and subsequent wind dispersal of the waste material.

- Prevent direct contact with waste material by people or animals.

- Prevent accumulation of liquids within the disposal site beneath the cover (bathtub effect).

- Accommodate pressures which may result from gas generated within the wastes.

\subsubsection{Protect from Percolation of Rainwater}

The final cover will consist of a sloped multi-layer system which will greatly reduce percolation of rainwater into the buried waste. Final design of the cover will be in accordance with DOE and EPA guidelines and SCDHEC Hazardous Waste Management Regulations. Regularly scheduled inspections of the cover will be carried out during the institutional control period to identify any local surface depressions or pooling of water. These areas of subsidence will be remedied as described in section 3.5 . 


\subsubsection{Promote Drainage and Prevent Erosion}

The final cover design will provide for runoff from the site to be intercepted and directed off-site by engineered ditches. Slopes of the cover surface will provide for sheet flow runoff at velocities below the threshold for erosion of the soil surface. Erosion will be further controlled by the establishment of a suitable shallow-rooted vegetative cover on the cap. Regularly scheduled inspections will be carried out during the institutional control period to ensure that any erosion or conditions leading to erosion are promptly detected and corrected.

\subsubsection{Minimize Maintenance}

The closure system will be constructed of naturally occurring materials which are stable in the SRP environment. They will be arranged in a system which will provide long-term protection of the waste with little or no maintenance.

\subsubsection{Protect Against wind Dispersal of waste}

The disposal site will be covered with a multi-layer cap consisting of compacted native soil, compacted clay, gravel, top soil and vegetation. These materials will provide protection of the buried waste against wind erosion and dispersal.

\subsubsection{Protect Against Contact with waste by Human and Animal Intruders}

Direct contact with waste at $643-\mathrm{G}$ will be prevented by existing site security and by the site cover. There are positive security measures in place which prevent movement of people and large animals on the site. Protection from small animals (rodents, insects, etc.) will be provided by the cap design. These measures will remain in effect throughout the institutional control period of the SRP site.

\subsubsection{Prevent "Bathtub Effect"}

The final cover will have a permeability less than the most impermeable component of the disposal site or the underlying soils to prevent the site from filling with water after closure. Field tests will be performed to quantify the range of permeabilities in the subsurface of 643-G, and the cap permeability will be designed to be less than that of the least permeable material found.

\subsubsection{Accommodate Gas Pressures}

Gas generation is generally associated with municipal waste or certain types of industrial waste. The types of waste disposed of in 643-G are not expected to generate gas except in very small quantities. Any gas which might have been generated after disposal has dissipated in the time that $643-G$ has been inactive. 


\subsection{Operational History}

\subsubsection{Geographical Location}

The $643-G$ radioactive waste disposal site was used to dispose of all radioactive solid waste produced at the plant as well as periodic shipments from other U. S. Department of Energy facilities from 1952 to 1974 (Figure 1). This site occupies 76 acres between the $F$ and $H$ Separations Areas approximately 6 miles from the nearest plant boundary. The 643-G site is a quadrilateral shape with corners at the following coordinates:

\section{SRP Coordinates (ft)}

N75, 277

N76, 150

N73, 900

N73, 346
$E 54,411$

E55, 081

E58, 080

E575860

\section{Latitude}

$33.28104^{\circ} \mathrm{N}$

$33.28407^{\circ} \mathrm{N}$

$33.28393^{\circ} \mathrm{N}$

$33.28195^{\circ} \mathrm{N}$
Longitude

$81.66975^{\circ} \mathrm{W}$

$81.66968^{\circ} \mathrm{W}$

$81.65749^{\circ} \mathrm{W}$

$81.65764^{\circ} \mathrm{W}$

\subsubsection{History of Disposal}

The 643-G disposal site was divided into sections for accommodating disposal of various levels and types of radioactivity in waste materials: transuranium (TRU) alpha wastes, low-level waste (alpha and beta-gamma), intermediate-level beta-gamma, and waste generated offsite. The disposal site was operated in compliance with $\mathrm{AEC}$ regulations regarding radioactive waste

disposal. Examples of materials which have been disposed include:

- Contaminated equipment - obsolete or failed tanks, pipes, jumpers, and other process equipment from the radiochemical separations areas.

- Reactor hardware and resins - fuel components and housings not containing irradiated fuel, and spent deionizer resins.

- Spent lithium-aluminum targets - the waste target alloy after tritium has been extracted.

- Oil from the tritium facilities, reactor areas and separations areas - before bulk storage was started, the oil was placed in drums containing an absorbant material and buried.

- Scintillation fluid.

- Mercury from gas pumps in the tritium facilities - before 1968, radioactively contaminated mercury was buried in one-liter polyethylene bottles contained within $0.02 \mathrm{~m}^{3}$ steel cans. Approximately $10,000 \mathrm{~kg}$ of mercury are buried in $643-\mathrm{G}$.

- Cadmium from control rods and neutron shielding sheets.

- Incidental waste from laboratory and production operations small equipment, spent air filters, clothes, analytical waste, decontamination residues, plastic sheeting, and gloves. 


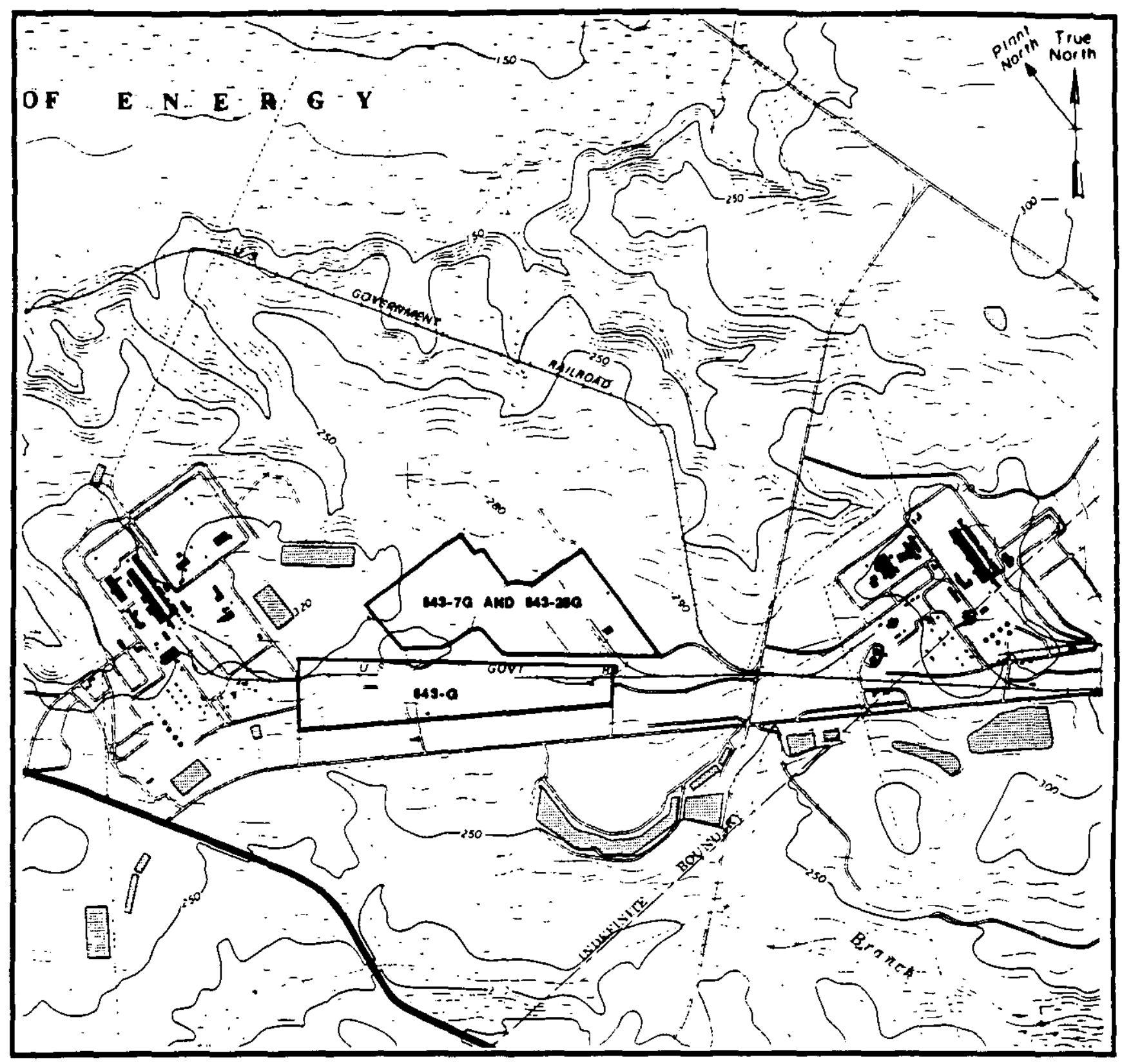

SCALE 124000

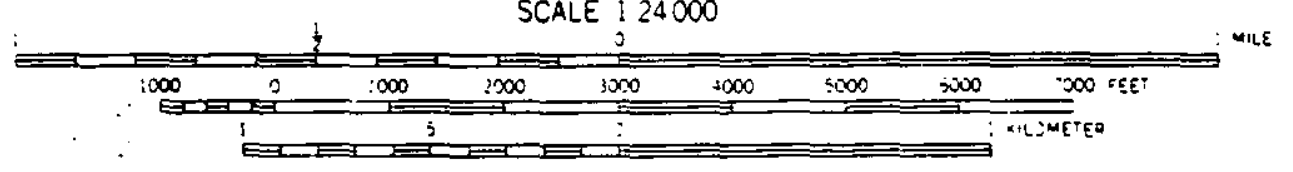

CONTOUR INTERVAL 10 FEET

DOTTEO LINES REPRESENT $=$ FOD: CON'JUAS

Figure 1 Map of the Radioactive Waste Burial Ground Area 
The estimated curie content of solid radioactive waste and mass of hazardous materials buried in 643-G are shown in Table 1 . The majority of this waste is contained in plastic bags and cardboard boxes and is thus subject to leaching when contacted by water-saturated soil.

Waste contaminated with beta-gamma emitters was separated into two categories for burial: low-activity beta-gamma and intermediate activity beta-gamma. Low-activity beta-gamma waste was defined as waste radiating less than $50 \mathrm{mR} / \mathrm{hr}$ at 3 inches from an unshielded package, less than $50 \mathrm{mR} / \mathrm{hr}$ at 10 feet from the truck load, and less than $0.1 \mathrm{Ci}$ of alpha activity per package. 2 scrap uranium from the fuel fabrication operation was also placed in these trenches. Intermediate activity waste was defined as that exceeding $50 \mathrm{mR} / \mathrm{hr}$ at 3 inches from an unshielded package. Intermediate activity waste was buried in separate trenches. Most waste forms generated offsite are buried in SLB trenches that are segregated from SRP waste.

Until 1965, alpha-bearing waste was buried in plastic bags and cardboard boxes in earthen trenches designated specifically for this waste. Between 1965 and 1974, alpha-bearing waste was segregated into two categories. Waste containing less than $0.1 \mathrm{Ci}$ per package was buried unencapsulated in alpha trenches. Waste containing greater than $0.1 \mathrm{Ci}$ per package was buried in retrievable concrete containers 7 feet in diameter and 7.5 feet high. Waste that did not fit into the concrete containers was encapsulated in concrete and buried. Canyon equipment and other bulky wastes contaminated with alpha-emitting nuclides and also intensely contaminated with gamma emitters were placed directly in shallow Land Burial (SLB) trenches. Inorganic constituents such as lead (used to shield a variety of waste forms or discarded due to high radiation levels) and cadmium (from control rods, safety rods, and shielding) have been placed in the disposal site.

Disposal trenches were excavated about 20 feet wide, 20 feet deep, and up to hundreds of feet long. The waste forms emplaced in the SLB trenches were covered with soil shortly after emplacement to maintain radiation control, to minimize the potential for fire, and to reduce potential for contamination spread. All trenches were backfilled with a minimum of 4 feet of soil to reduce surface radiation rates to less than $5 \mathrm{mrem} / \mathrm{hr}$, to reduce the potential for contaminant spreading, and to minimize plant and animal intrusion into the waste.

A paved road to the entrance and many unpaved roads inside the fenced disposal site provided access for trucks, the usual mode of transportation for solid waste. A railroad spur permitted shipments of large pieces of equipment from operating areas and offsite.

Beginning in 1962 records were kept of the contents, radiation level, and approximate location of each shipment of waste. ${ }^{3}$ All shipments were described by the waste generator. This information was recorded, and permanent computerized and microfilm records were maintained. The location of the burial area for each shipment of waste is defined by a 100 foot grid system. The 100 foot grids are further divided into 20 foot squares. 
TABLE 1

INVENTORY OF HAZARDOUS AND RADIOLOGICAL CONSTITUENTS AT THE 643-G SITE

Nuclides

$\mathrm{H}-3$

$\mathrm{C}-14$

Co- 60

$\mathrm{Ni}-59$

$\mathrm{Ni}-63$

$\mathrm{Se}-79$

$\mathrm{Rb}-87$

Sr-90

$\mathrm{Y}-90$

TC-99

Ru-106

$\mathrm{Sb}-125$

Te-125m

I-129

Cs -134

Cs -137

Pm-147

Sm-151

Eu-154

Eu-155

Th-228

Th-232

$\mathrm{U}-233$

$\mathrm{U}-234$

$\mathrm{U}-235$

$\mathrm{U}-238$

$\mathrm{Np}-237$

Pu-238

Pu-239

Pu-241

Pu-242

Am-241

Am-243

Cm-244

$\mathrm{Cm}-248$

\section{Chemical and Metals}

Cadmium

n-Dodecane

Lead

Mercury

Naphthalene

Toluene

Tributylphosphate

Trimethylbenzene

xylene

\section{Inventory (Ci)}

$2.6 \times 10^{6}$

$5.4 \times 10^{-3}$

$1.3 \times 10^{6}$

$1.8 \times 10^{3}$

$4.6 \times 10^{5}$

$5.0 \times 10^{-1}$

$3.2 \times 10^{-5}$

$1.1 \times 10^{5}$

$1.1 \times 10^{5}$

$1.7 \times 10^{1}$

$1.0 \times 10^{4}$

$3.0 \times 10^{3}$

$7.3 \times 10^{2}$

$2.9 \times 10^{-2}$

$1.2 \times 10^{4}$

$1.1 \times 10^{5}$

$8.5 \times 10^{4}$

$8.3 \times 10^{2}$

$2.2 \times 10^{3}$

$1.7 \times 10^{3}$

$1.3 \times 10^{-2}$

$3.6 \times 10^{-2}$

$2.3 \times 10^{-1}$

$3.5 \times 10^{0}$

$3.1 \times 10^{-1}$

$1.6 \times 10^{1}$

$2.0 \times 10^{0}$

$2.1 \times 10^{4}$

$1.4 \times 10^{3}$

$2.9 \times 10^{3}$

$2.1 \times 10^{-2}$

$3.0 \times 10^{1}$

$2.0 \times 10^{-2}$

$3.7 \times 10^{4}$

$1.6 \times 10^{-6}$

Inventory $(\mathrm{kg})$

$1.2 \times 10^{3}$

$1.7 \times 10^{3}$

$5.5 \times 10^{4}$

$1.0 \times 10^{4}$

$2.2 \times 10^{3}$

$7.1 \times 10^{3}$

$7.2 \times 10^{2}$

$7.1 \times 10^{3}$

$1.2 \times 10^{4}$ 
A series of twenty-two tanks were used for the storage of spent solvent. These tanks have since been emptied.

\subsection{Closure Actions - stabilization, waste Removal, Capping \\ 2.1 stabilization}

There are 22 empty spent solvent storage tanks within the 643-G site. The present reference plan is to stabilize these tanks in-place by filling them with grout. 4

The existing grid well network within the 643-G site will be removed and properly closed. This program is being carried out by Waste Management Technology. 5

\subsection{Naste Removal}

Prior to the construction of the TRU pads in the 643-7G disposal site, concrete containers of waste contaminated with $239 \mathrm{Pu}$ and $237 \mathrm{~Np}$ were placed in retrievable storage in earthen trenches within 643-G. A performance assessment was conducted by Rogers and Associates Engineering Corporation to evaluate a variety of remediation and capping options ${ }^{6}$. The performance assessment showed that long-term releases from the site will be greatly reduced by the removal of this material. Ideally, the removal of the buried culverts would be done prior to the installation of the cover system, but the facilities to remove and repackage the waste may not be ready at the time that closure is performed. In this case a separate plan for cap removal, waste exhumation, and cap repair will be prepared.

The performance assessment showed that with a cap system which maintains long-term effectiveness, no other waste constituent will pose a danger to the environment beyond the one-hundred year institutional control period.

\section{3 closure cap}

The performance assessment ${ }^{6}$ demonstrated that any capping material with an effectiveness greater than natural SRP soil would result in lower doses at the boundary well. The less water which percolates through the cap the lower the doses and the greater the time of arrival at the boundary well. Caps constructed of concrete or synthetic membranes are very effective in the short term (tens to hundreds of years), but their long term (thousands of years) ability to prevent infiltration through leaks and cracks cannot be proven.

Clay minerals are naturally occurring materials which are the result of long periods of weathering, and which have been thermodynamically and kinetically stable for millions of years in the subsurface. Large deposits of kaolinite of Eocene Age occur in Aiken county.7 Extensive deposits of smectite (bentonite) of cretaceous Age are found in wyoming.8 The existence of these deposits over geologic time gives credence to the assumption that clay caps will perform well as closure covers over long periods of time. 
The performance assessment assumed an infinite life and a small infiltration rate $(0.02 \mathrm{~m} / \mathrm{yr})$ for clay covers. Earthen covers were assigned an infinite life and normal SRP infiltration $(0.38 \mathrm{~m} / \mathrm{yr})$. Synthetic membranes and concrete were given effective lives of 40 and 100 years, respectively, and zero infiltration during that time. After the effective life the infiltration rate changed to that of the surrounding cap material, either native soil or clay.

Based on the performance assessment, a closure cap consisting of a low-permeability clay layer has been selected. The addition of an overlying gravel drainage layer is considered necessary to maintain long-term performance.

\subsubsection{Cover Design Configuration}

The cover design configuration is shown in plan view in Figure 2 and in cross section in Figure 3. This cover design configuration has been developed to meet the following criteria:

- Maintain a minimum of six feet of cover over the waste.

- Drainage lines and surfaces should have a slope of 5 percent. This will allow for some future subsidence and still maintain sufficient slope to remove surface runoff.

- No drainage lines should cross trenches or other areas where waste is known to be buried. This will assure that localized subsidence will not cause water to collect in drainage lines and overflow into waste-containing areas.

- The slopes at the edge of the cap should not exceed I vertical to 4 horizontal to minimize the potential for slope failure and erosion.

This cover design may result in some slopes greater then 3 to 5 percent. If steeper slopes do result, special provisions will be provided which will include concrete-lined slope gutters and other measures if estimated sheet erosion could exceed guidelines.

All slopes will be stable with respect to soil mass stability. These slopes will also be suitable with respect to support of vegetation and mowing operations, as well as other maintenance activities.

\subsubsection{Cover Cap Construction}

\section{surface Preparation}

No soil removal from or grading of the existing surface of 643-G will be permitted, due to health physics concerns. A one-foot thick layer of clean soil material must be placed on the existing surface before outside contract personnel will be allowed to work in the area. The soil for this layer can be any clean source of random borrow material. 
Eigure 2

\section{PLAN VIEW OF CAP DESIGN}
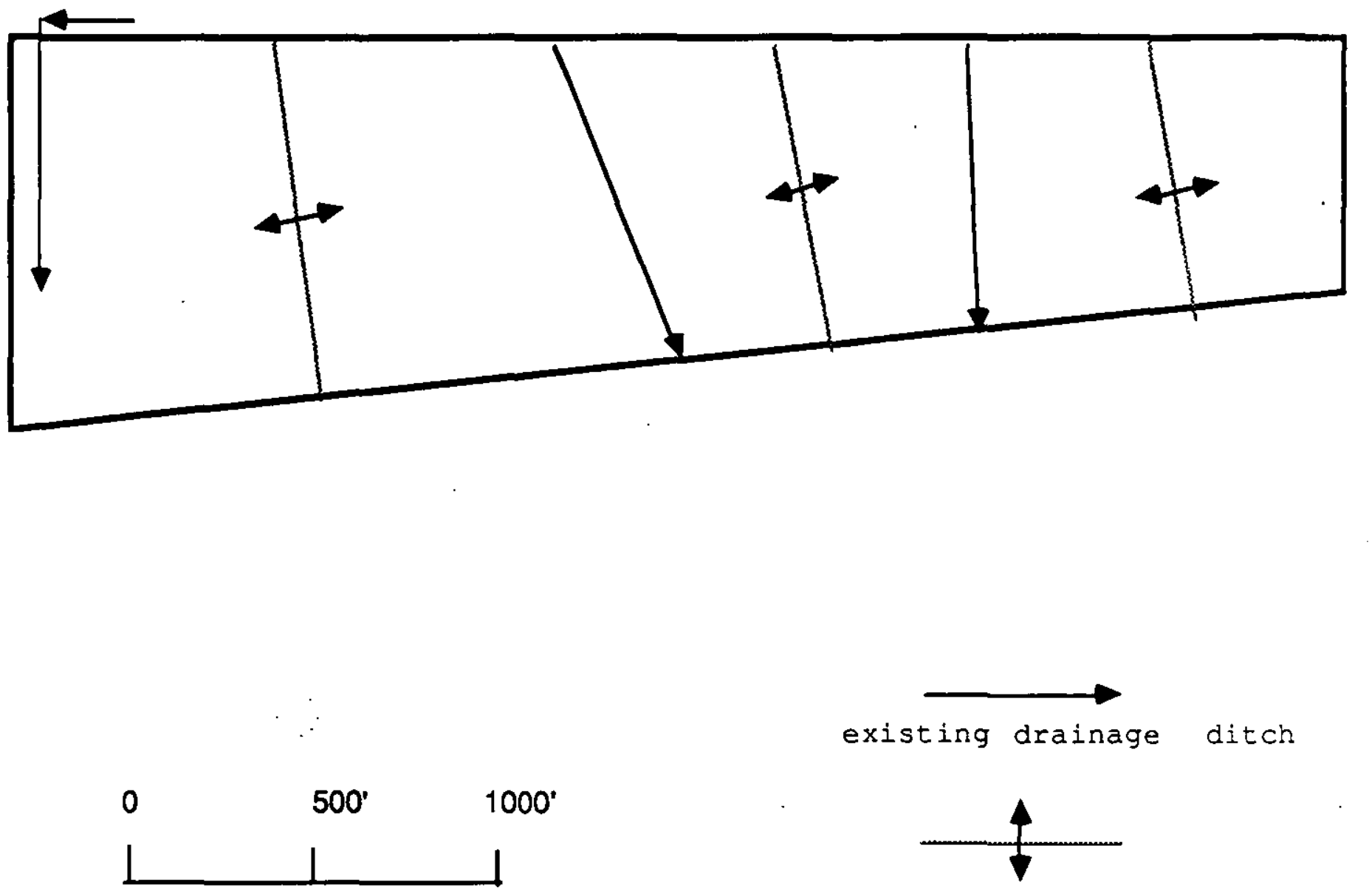

cap peak centerline 


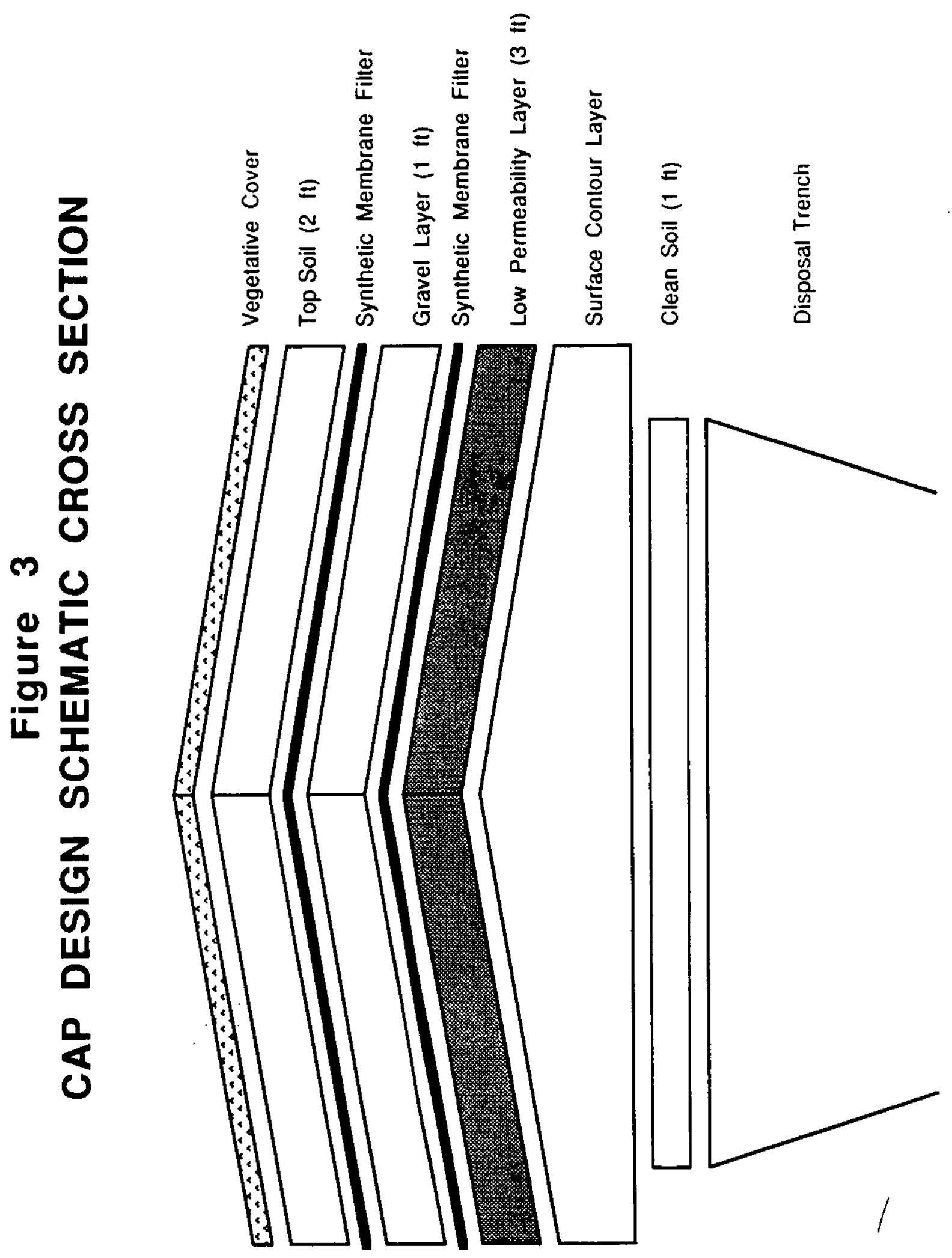




\section{Surface Contour Layer}

The final cap surface topography will be a series of peaks and valleys which will be used to control surface drainage. This final surface will differ from the existing Burial Ground topography. A surface contour layer consisting of native soil will be constructed so that its top surface is six feet below the top of the final cap surface at all locations. The layer will be compacted with a sheepsfoot roller or other suitable heavy equipment to improve structural integrity. The native soil will be placed in lifts not to exceed 12 inches in thickness, moisture conditioned where required, and compacted with a sheepsfoot or other appropriate type of compactor. If the soil is too wet, it will be aerated prior to placement. Each layer will be compacted to at least $90 \%$ of the maximum dry density at optimum moisture content.

\section{Low-Permeability Layer - Compacted clay}

The low-permeability compacted clay component of the cover will be a minimum of 36 inches in thickness and will possess a maximum hydraulic conductivity of $1 \times 10^{-7} \mathrm{~cm} / \mathrm{sec}$. A study will be conducted to identify appropriate sources of material for the construction of the compacted clay layer. Candidate low permeability materials will be tested to provide parameters to be used for construction quality control and verification of in-situ low-permeability performance.

After the surface contour layer has been regraded and prepared, clay materials will be placed in lifts not exceeding six inches in thickness. Each lift will be compacted so as to provide the required permeability of the clay layer. Moisture contents of layers to be compacted will be slightly greater than optimum moisture content. At selected locations, field tests will be performed during construction to verify compliance with design performance requirements. Any areas found to be substandard will be removed, replaced and/or repaired to meet design requirements. At no time during installation will desiccation of the clay material be allowed.

\section{Gravel Layer}

A one-foot thick layer of clean, coarse (1 to 2 inch diameter) gravel will be placed on top of the low-permeability layer. The gravel will be both underlain and overlain by a synthetic membrane filter. The lower membrane will prevent the gravel from entering the clay layer below. The upper membrane will prevent soil material from washing into the gravel layer and affecting its performance.

The gravel layer will serve four purposes:

- Under normal, unsaturated, conditions, the gravel will act as a capillary barrier; that is, the large pores of the gravel material will inhibit capillary flow from the overlying soil.9 
- Under saturated conditions, such as might occur after very heavy rainfall, the gravel layer will serve as a high permeability conduit to drain water laterally off the clay cap and to the drainage ditches.

- The gravel layer will tend to increase the water content of the overlying soil, thus aiding the vegetative cover. The gravel layer itself will have a low water content and will thus inhibit root growth into the clay.

- Extensive layers of gravel are not found in the coastal Plain material in the vicinity of the Savannah River Plant, so this layer should serve as a warning to a human intruder that non-natural conditions exist at the site.

\section{Final Cover}

The final cover will be a layer with a minimum thickness of two feet consisting of native silty fine to medium sands having a permeability of approximately $1 \times 10^{-3} \mathrm{~cm} / \mathrm{sec}$. This layer must be capable of supporting vegetation. The final cover material will be free of objectionable material which would prevent satisfactory compaction or cause damage to the underlying portions of the cap system.

The placement of the initial layer of the final cover will be limited to a 12 inch thickness compacted to a minimum of 85 percent maximum dry density. The topmost layer of the final cover will be spread uniformly with the finished level at the design grade elevations.

\section{Vegetative cover crop}

The surface of the cover layer will be fertilized, seeded, and mulched. An initial cover crop of Bahia grass will be cultivated to minimize erosion. Studies are currently in progress to select a final cover crop. The requirements of this final cover crop are:

o. The vegetation should be a climax species, that is, is vigorous enough to naturally exclude all other competing plants. The climax species on the Savannah River Plant uplands is the Longleaf Pine tree.

- The vegetative cover crop should be shallow rooted so that it does not physically impact the gravel-clay cap system.

- The vegetation should provide a high evapotranspiration rate to minimize soil water reaching the cap system.

- The vegetation should be long-lived, easily established and maintained, readily available, and ecologically acceptable.

Initial results in test plots 10 show that several species of bamboo may meet the above requirements for a final cover crop. 


\subsection{Additional Design Considerations}

\subsection{Initial site conditions}

\subsection{1 soil conditions}

Based on borings in and around the Savannah River Plant site and trench excavation within 643-G, the soils in the disposal site consist of varying mixtures of sand, silt, and clay, with local occurrences of gravel. In order to carry out closure it will be necessary to establish a program of field borings to provide engineering data to assure that the Burial Ground soils have the bearing strength to support the cover system, and that the cap has a lower permeability than the underlying soils.

\subsubsection{Topography}

Estimated existing topography of the Burial Ground is shown in Figure 4. The source of these topographic data is a series of site maps prepared around 1963 while disposal activities were ongoing. The topography surrounding $643-\mathrm{G}$ should be accurate since these areas have not been disturbed. However, this is not true for all the areas inside the site boundary. Some of these areas have been altered by disposal operations. Based on a recent reconnaissance of the site, some critical areas are thought to be at or near their pre-1963 ground elevations. These areas include the main drainage ditches and the perimeter fences.

A detailed topographic map of $643-\mathrm{G}$ and the surrounding area has been prepared. Photogrammetric methods and field measurements were used to develop a 2 -foot contour interval topographic map. The Burial Ground slopes toward the southeast corner, ranging in elevation from 300 feet to 280 feet at the site boundaries.

\subsection{Materials}

Borrow material for the closure cover will be composed of suitable soils from within the SRP property if practical. Sources of suitable borrow material for the cover will be investigated both within and outside plant property. This study will include reviewing available data from previous studies, a detailed reconnaissance, study of available aerial photographs, and a drilling/test pit exploration program. Soil samples from borings and bulk samples from test pits will be analyzed and tested. Index tests such as grain size analysis and Atterberg Limits will be performed to determine the moisture-density relationships. Permeability tests will be performed on remolded samples compacted to the same compaction requirements to be used in the cap design to determine the permeability characteristics of the cap. These tests are necessary to identify suitable soils for construction of the surface contour layer and the low-permeability cover. 


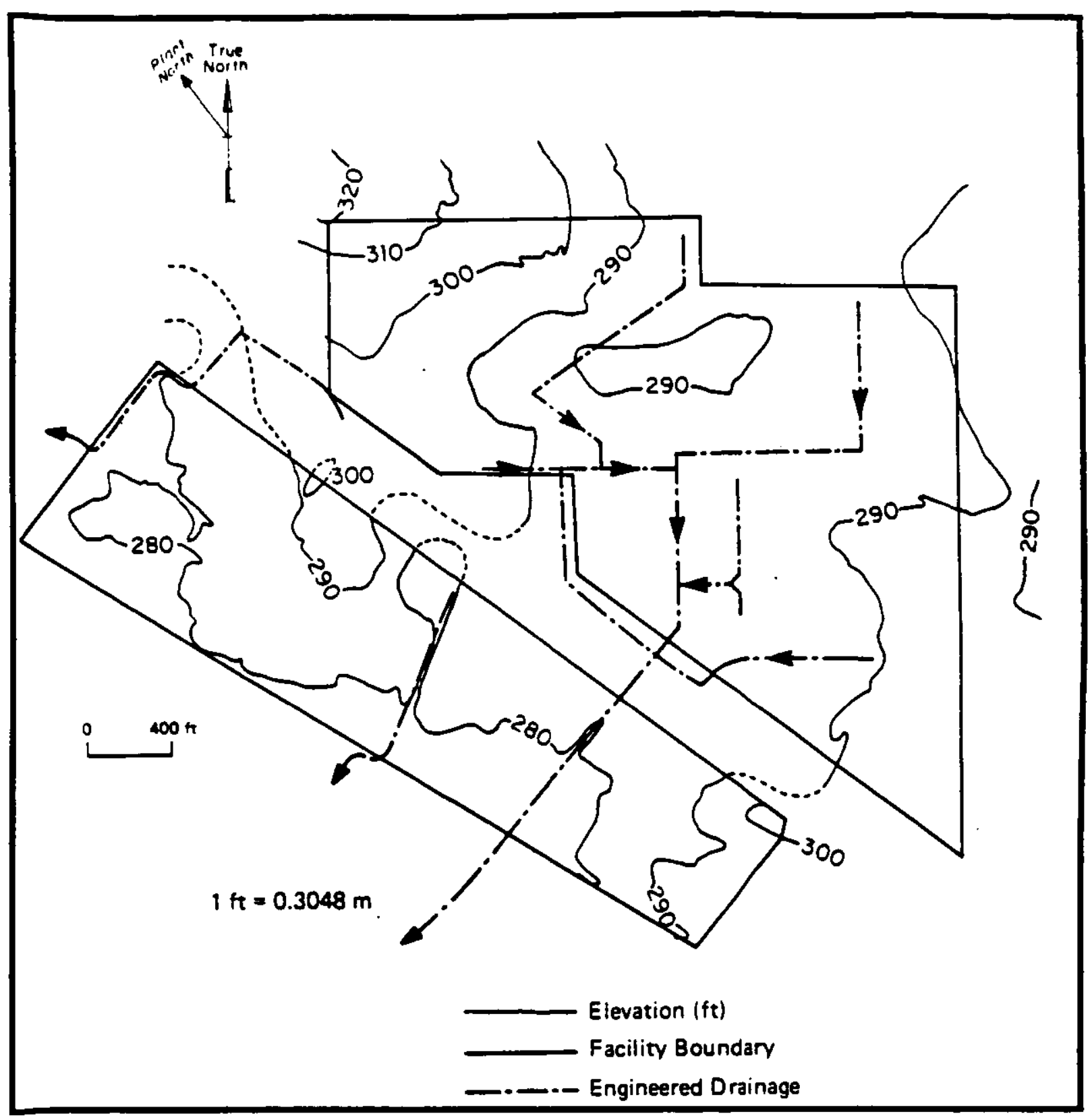

Figure 4 Topography and Drainage in the vicinity of the $643-G$ Radioactive Waste Burial Ground 


\subsection{Surface Drainage and Erosion control}

The final cover surface configuration is intended to provide slopes of from 3 to 5 percent for control of surface runoff. Since the 643-G site has an area of 76 acres, the control of surface water is an important consideration in the closure system design (average rainfall over the area of $643-G$ will result in 93 million gallons of water per year). The drainage design concept must meet the following criteria:

- Off-site storm water is to be prevented from entering the disposal area either by a series of interceptor ditches, by natural topography, or by a combination of both.

- The cover is designed to exclude virtually all infiltration. Therefore, the large volume of water which normally would infiltrate must be removed from the site using a surface drainage system. An NPDES storm water outfali may need to be provided as part of the surface drainage system.

- The main drainage ditches adjacent to the disposal area should be concrete lined to prevent erosion, and be underlain by an impermeable membrane to prevent storm water in the ditches from seeping laterally into the waste disposal areas.

Details concerning the surface drainage and erosion control system are discussed in the following sections.

\subsubsection{Runoff Analysis}

This section contains details of the proposed engineering analysis leading to the design of the surface drainage and erosion control system. Studies that will address concerns about the proper engineering design of the proposed system are discussed in the following sections.

\section{Precipitation Records}

Table 2 contains the monthly mean precipitation at Augusta, Georgia, for the 30-year period ending in 1980. The Augusta station is a major, long-term National oceanic and Atmospheric Administration (NOAA) station located about 20 miles west-northwest of the 643-G Burial Ground site. More than 80 years of rainfall records are available for the station; however, evaporation records are not available. Thus, the station is a source of data for storm runoff analyses, but may not be particularly valuable for infiltration studies without a concurrent evaporation record.

As discussed in the following sections, the rainfall events will be selected for analysis by considering long-term records at many stations. These data will be presented in the form of isopluvial maps. Such maps are based on regional analyses of available data and give a reasonable estimate of rainfall intensity and frequency of such storms. 


\section{Evapotranspiration}

For the purpose of making infiltration estimates, average monthly evapotranspiration will be based on records of evaporation, applying a correction factor appropriate for the Burial Ground.

The nearest weather stations having both precipitation and evaporation data are Blackville, South Carolina, and Clark Hill Dam, Georgia, located 18 miles east-northeast and 42 miles northwest of the Burial Ground, respectively. These data will be obtained. Data from one of the two stations will then be used to estimate Burial Ground infiltration rates. Criteria for the selection will include completeness of the record, length of record, and proximity to the 643-G site.

\section{Design storm}

For the purpose of determining the design hydraulic capacity of drainage features, the 100-year storm runoff event will be used. Rainfall intensities and frequencies are presented in Table 3 . These data are taken from the U. S. Weather Bureau Technical Paper No. 40.11 The data are based on regional analyses of many long-term rainfall records.

Design discharges at key points in the drainage system will be calculated using methodology developed by the soil Conservation Service (SCS) and presented in Technical Release No. 55.12 The procedure includes the provision for dividing a watershed into several subareas, defining each subarea in terms of runoff characteristics (time of concentration, runoff curve number, drainage area, etc.), and computing the resulting discharge at the outlet of each subarea. The procedure takes into account the relative travel times from point to point along drainage courses in the watershed in order to account for temporal phasing of the resulting hydrographs.

\section{Infiltration Evaluation}

The intended purpose of evaluating infiltration is to estimate the amount of percolating water that will penetrate through the cover soil and reach the waste material. However, the proposed cover design provides for a low-permeability layer that will prevent most infiltrating water from reaching the waste. Therefore, the importance of the infiltration evaluation in this case is greatly reduced. Such an analysis will be useful, however, to assess the adequacy of the drainage layer proposed to be placed immediately above the low-permeability layer. 
TABLE 2 PRECIPITATION DATA FROM SRP AND VICINITY

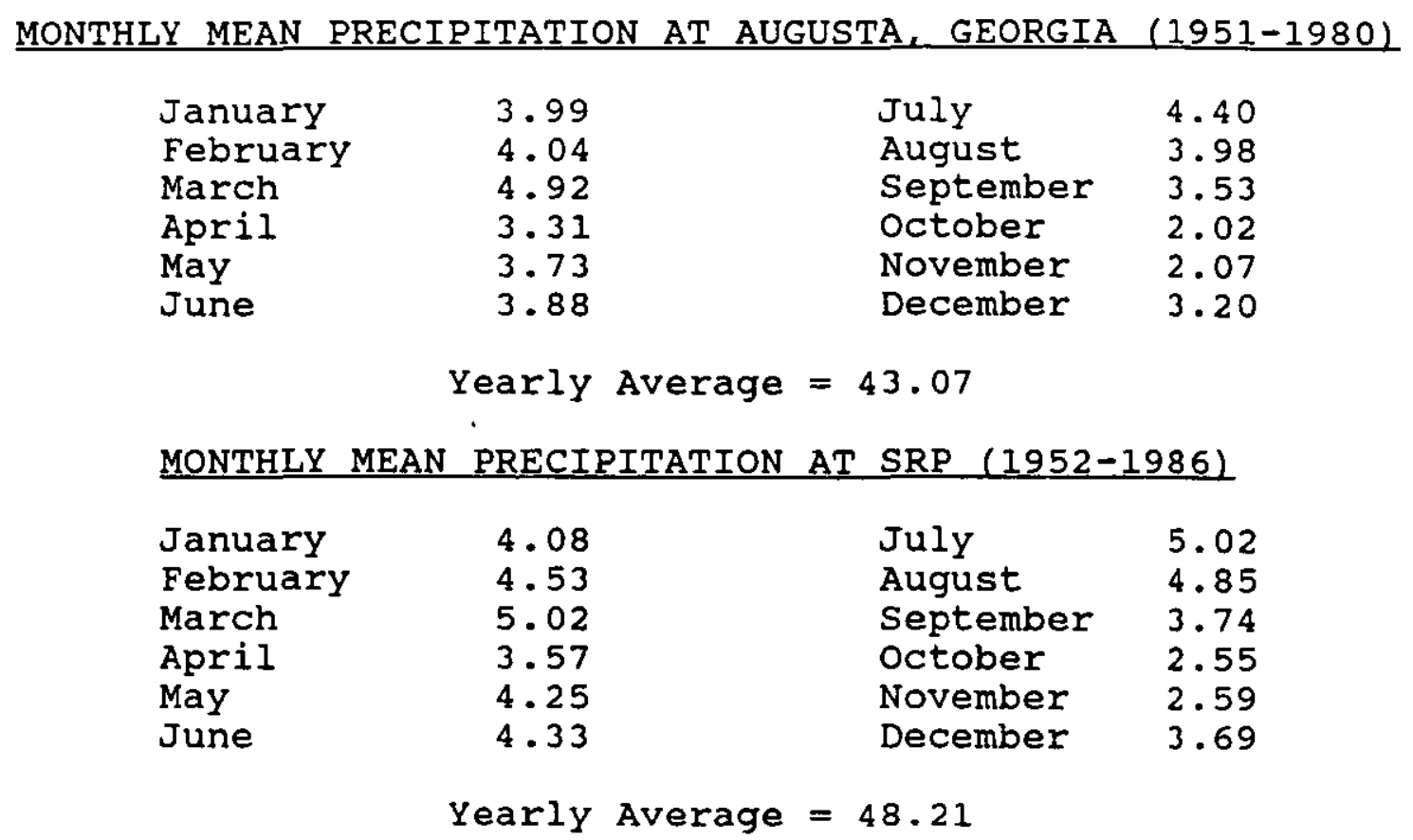

MONTHLY MAXIMUM PRECIPITATION AT SRP (1952-1986)

$\begin{array}{lrlr}\text { January } & 10.02 & \text { July } & 11.48 \\ \text { February } & 7.94 & \text { August } & 12.34 \\ \text { March } & 10.96 & \text { September } & 8.71 \\ \text { April } & 8.20 & \text { October } & 10.86 \\ \text { May } & 10.90 & \text { November } & 6.46 \\ \text { June } & 10.89 & \text { December } & 9.55\end{array}$

Yearly Maximum $(1964)=73.47$ 
TECHNICAL DATA SUMMARY

$-18-$

DPSTD $-87-2$

TABLE 3

RAINFALL INTENSITY AND FREQUENCY (inches)

\begin{tabular}{rrrrrrrr}
$\begin{array}{r}\text { Frequency } \\
\text { Years }\end{array}$ & 0.5 & 1 & 2 & 3 & 6 & 12 & 24 \\
\hline 1 & 1.3 & 1.6 & 1.9 & 2.1 & 2.5 & 2.8 & 3.3 \\
2 & 1.5 & 1.8 & 2.2 & 2.5 & 3.0 & 3.5 & 3.8 \\
5 & 1.8 & 2.3 & 2.8 & 3.0 & 3.7 & 4.3 & 5.0 \\
10 & 2.1 & 2.6 & 3.2 & 3.5 & 4.3 & 5.0 & 6.0 \\
25 & 2.4 & 3.0 & 3.7 & 4.0 & 5.0 & 6.0 & 6.8 \\
50 & 2.6 & 3.3 & 4.1 & 4.5 & 5.5 & 6.5 & 7.5 \\
100 & 2.9 & 3.7 & 4.7 & 5.0 & 6.3 & 7.6 & 8.3
\end{tabular}

Source: U. S. Department of Commerce, 1963. 
The infiltration evaluation required for final cap drainage design will consist of a somewhat abbreviated water balance similar to that suggested by the EPA. 13 The analyses will use local precipitation and evaporation records taken from a single station, considering selected soil types and vegetation proposed for cover; the amount of percolation for each month of the year will be estimated.

\subsubsection{Erosion Potential}

Erosion at the site may occur in several forms: sheet erosion on the slopes in the cap soil, rill or gully erosion along the edges of the cap and sides of drainage ditches, and scour erosion along drainage courses. Losses of soil from the movement of water can be minimized by proper design.

The sheet erosion analysis of the final cap surface design will be made using an acceptable method such as the Universal soil Loss Equation which was developed by the USDA 14 . Provisions used in the design of the cap to minimize sheet erosion include the following:

- Surface slopes will be minimized to the extent possible, keeping in mind requirements and criteria for proper drainage

- Slope lengths will be limited to 300 feet (maximum).

- Lined slope gutters will be provided on slopes exceeding 8 percent and where the slope length would otherwise exceed 100 feet. In such cases, the gutters will be placed so that slope lengths will be limited to about 100 feet. Each gutter will have a 5 percent slope.

- The best possible area-compatible surface vegetation will be provided for erosion control.

In the event that the analysis indicates that the above annual soil loss criteria cannot be achieved for any particular portion of the cover, other measures will be considered including the use of special erosion-resistant soils, providing extra soil thickness, and the application of surface treatment on limited areas.

\subsubsection{Drainage system}

Off-site storm water will be prevented from entering the disposal site by a series of interceptor ditches in the upslope perimeters of the site where drainage is toward the Burial Ground due to natural topography. These ditches will convey water away from the site. The hydraulic capacity of the ditches will be designed to ensure that they are adequate to handle a 100-year storm runoff event. At other perimeter areas, the natural topography will drain runoff away from the disposal site. 
The proposed design will provide for downslope drains spaced at 200-foot (maximum) intervals along the toe of the cap. Runoff from upslope will be prevented from uncontrolled discharge over the cap edge by the placement of a concrete curb and gutter along the edge of the cap. Upon reaching the curb, runoff water will be directed laterally along the gutter to the nearest downslope drain. These drains will be lined with concrete to prevent erosion. Also, the discharged water from each downslope drain will be conveyed through a lined channel to the nearest drainage ditch. All drainage ditches within the site boundary will also be lined with concrete. This will prevent gully erosion at downslope drain discharge points as well as scour erosion along the ditches.

The surface of the cap is designed to drain rainfall runoff over a series of plane surfaces and through various lined gutters toward lined downslope drains. The slope for all plane surfaces should be 5 percent. This criterion is proposed to allow for any compaction and subsidence and still maintain a long-term slope of 3 percent. After discharging through the downslope drains, the runoff will then be conveyed away from the cover and toward a system of drainage ditches. In areas of concentrated fiow, lined gutters or drains will be used to prevent excessive erosion.

\section{Ditch Design}

As discussed above, the soil Conservation Service TR-55 methodology or its equivalent will be used to compute ditch design discharges resulting from a 100-year storm runoff event. The TR-55 model or its equivalent will provide design discharges at selected key points along the ditches in question. The Manning Equation will be used to check the capacity of existing ditches considering the improved roughness coefficient provided by the proposed concrete lining. Ditches found to be inadequate will be increased in size or otherwise redesigned. Proposed ditches will also be sized using the Manning equation. Resulting discharge conditions will be checked for the presence of supercritical flow conditions which might cause the formation of hydraulic jumps with attendant undesirable hydrodynamic forces. If such conditions are found to be potentially present, design modifications will be investigated.

Culvert Design.

Using various nomographs available in design manuals, each culvert will be checked for its hydraulic capacity. Design discharges obtained from the TR-55 model will be used in the analysis. Should any culvert be found to be inadequate, design modifications will be implemented including improved inlets and the addition of extra pipes, as well as complete replacement.

\subsection{Subsidence}

For the long-term successful performance and maintenance of grades for drainage, it is necessary that the final cover be designed to accommodate any subsidence that may occur. Subsidence could be due to compression of either the foundation or the waste. 
Physical characteristics of the waste at the Burial Ground are quite typical of industrial landfills, and future subsidence is expected to be similar, also. The waste in 643-G was contained in cardboard boxes or plastic bags and covered with soil daily. These practices resulted in immediate compaction of the waste, so that little long-term subsidence would be expected. The 643-G site has been inspected on a regular basis for signs of subsidence. Small depressions have been found and corrected with clean backfill, but no large subsidence features have been observed. The site has been inactive since 1974, so little if any future subsidence is expected.

\subsubsection{Compression of Foundation}

Subsidence of the final cover can result from compression of the foundation due to the overlying weight of the disposed waste, backfill material, initial or grading fill, and the weight of the final cover itself. This subsidence, which can be predicted using normal geotechnical engineering design methods, consists of several components: elastic compression which occurs essentially as load is applied; primary consolidation which occurs over a period of time as water is expelied from the soil voids in the foundation soil; and secondary consolidation/creep which occurs slowly over a long period of time in certain soils. In addition, certain soils are subject to loss of strength and subsidence due to earthquake shaking, or liquefaction. The SRP area is not prone to earthquakes.

The subsurface soil investigation and laboratory testing program will identify soil engineering properties to determine subsidence data for the foundation soils. Based on the present knowledge of soil conditions at the site and the fact that the Burial Ground has been inactive for a number of years, it is expected that subsidence of foundation soils will be minor. Preliminary indications are that the foundation soils will not be subject to secondary compression or creep, nor to liquefaction.

\subsubsection{Compaction of waste}

Compression of waste material in a disposal site normally is the result of dewatering of the waste material, biological oxidation of organics, and chemical decomposition. It is believed that the Burial Ground wastes largely consist of plastic, wood, and paper. The remainder consists of scrap metal, rubble, and process vessels and equipment, and various other materials. These waste materials have been disposed of in earthen trenches. Little subsidence is expected to occur from dewatering. The nature of the waste is such that both biological oxidation of organics and chemical decomposition are minor components of total subsidence. The most significant compression of waste results from consolidation of waste under the weight of backfill material. Most of this compression took place rapidly as load was applied. Additional subsidence occurs over a period of time as the backfill soil consolidates or densifies. Very little information is available concerning the subsidence behavior of waste filled trenches. However, observation of backfilled trenches indicates that the compression of waste and backfill at the site has been minor and easily accommodated by occasional surface regrading. 


\subsubsection{Subsidence Monitoring}

After construction of the final cover, some long-term subsidence is expected. The objective of the design is to provide for a minimum of 3 percent final slope after subsidence has occurred. Initially, the final cover will have a 5 percent slope. Thus a considerable amount of subsidence can be accommodated before the minimum 3 percent slope would be achieved. One criterion for tolerable subsidence could be that subsidence which could be experienced without reducing the surface grade to less than 3 percent.

During the post-closure period, regularly scheduled monitoring of surface markers will reveal any area where subsidence has exceeded the established tolerable limits. Any area where the surface grade settles below the minimum required 3 percent or any area where a local depression or basin might develop can be detected during the monitoring period.

Subsidence will be monitored weekly during the construction period and prior to construction of the final cover. Thereafter through the post-closure monitoring period, subsidence markers will be monitored quarterly. The subsidence data obtained will be checked against the limiting elevations which have been defined as the limits of tolerable subsidence. Where subsidence is noted to exceed these tolerable amounts, remediation will be carried out.

\subsubsection{Subsidence Gauges}

Subsidence gauges will be constructed of 1/4-inch thick steel plates with dimensions of 12 inches by 12 inches. Short lengths of rebar will be welded near the four corners of the plate to serve as anchors for the subsidence plate when it is installed on the ground surface of the initial soil cover. A 1-inch outside diameter standard pipe coupling will be welded at the center of the plate and one-foot length of 1 -inch pipe attached to the coupling to serve as a survey pin. plates will be numbered individually to facilitate identification.

\subsection{Cap Repair}

If the subsidence monitoring program reveals an area where greater than tolerable subsidence has occurred, the cap will be reconstructed in such an area to restore a minimum of 5 percent surface grade. In general, reconstruction will be carried out as follows:

- The top cover layer will be removed and stockpiled.

- The required surface elevation to achieve the design slope will be determined. 
- The area will be regraded using random local fill to an elevation 5 feet below the required surface elevation.

- The final cover will be reconstructed.

- The gravel layer in the restored area will be made continuous with the gravel layer in the surrounding unrestored area in order to provide for continuous arainage of runoff.

\subsection{Post-closure Ground water Monitoring}

A program to install perimeter ground water monitoring wells at 643-G which are compatible with requirements of the Resource Conservation and Recovery Act is being implemented by Waste Management Technology. These wells will be sampled and analyzed on a regular basis to monitor closure performance throughout the institutional control period. 


\section{References}

1. Draft Environmental Impact statement, waste Management Activities for Groundwater protection Savannah River plant Aiken, South Carolina, U.S. Department of Energy, DOE/EIS-0120D, April 1987.

2. J. H. Horton and J. C. Corey, storing solid Radioactive wastes at the Savannah River Plant, DP-1366, June 1976.

3. G. F. Molen, COBRA/ADABAs Adhoc query system, DPST-81-457, November 1981 .

4. D. J. Zecha, Jr., Decommissioning solvent storage Tanks sl Through S22, Draft TA 2-1130.

5. 0. B. Wheat, Personnel Communication, August 1987.

6. James R. Cook, Performance Assessment of Closure Alternatives for the 643-G site - Rogers and Associates Engineering Corporation, DPST-87-268, February 9, 1987.

7. Bennett. F. Buie and Edward L. Schrader, south Carolina Kaolin, in Geological Investigations Related to the Stratigraphy in the. Kaolin Mining District, Aiken County, South Carolina, Paul G Nystrom, Jr. and Ralph H. Willoughby editors, Carolina Geological Society Field Trip Guidebook, October 1982 .

8. Robert L. Bates, Geology of the Industrial Rocks and Minerals, Dover Publications, 1969.

9. R. H. Hawkins, A Capillary Barrier for a Dry Burial Environment, DPST-83-317, February 1983 .

10. R. H. Hawkins, personnel communication, August 1987.

11. U.S. Department of Commerce, Rainfall Frequency Atlas of the United states, Weather Bureau Technical Paper No. 40, 1963.

12. U.S. Department of Agriculture, Soil Conservation Service, Hydrology for small watersheds, Soil Conservation Service Technical Release No. 55 (Revised), 1985.

13. D. G. Fenn and others, Use of the water Balance Method for Predicting Leachate Generation from solid waste Disposal sites, U.S. Environmental Protection Agency, EPA/530/SW-168. 1975 .

14. U.S. Department of Agriculture, Soil Conservation Service, Procedure for Computing sheet and Fill Erosion on Project Areas, Soil Conservation Service Technical Release No. 51 (Revised), 1975 . 